\title{
ABERTURAS E DESMORONAMENTOS NA EDUCAÇÃO
}

\author{
Antonio Carlos Dias Junior ${ }^{1}$ \\ Wenceslao Machado de Oliveira Junior ${ }^{2}$ \\ O chão é um ensino \\ Manoel de Barros
}

A Revista ETD - Educação Temática Digital publica seu quarto e último número de 2018. Duas edições temáticas e outras duas com publicações de demanda contínua configuram o resultado final de um trabalho coletivo que não seria possível sem a contribuição de autores e autoras, pareceristas, equipe técnica e editoria. A partir de 2017 iniciamos uma etapa na qual a fotografia de capa em cada número compõe e expressa, conceitual e imageticamente, as intenções acadêmicas e políticas a que almejamos. Nesse sentido, também somos gratos aos fotógrafos que contribuíram conosco nesse ano que se encerra.

Somos uma publicação multidisciplinar, cujo escopo têm em seu cerne a educação em suas múltiplas dimensões e potencialidades. Nossa missão reside em dar vazão a escritos que versam sobre temáticas, metodologias e abordagens as mais variadas. Publicamos artigos originais, mas também comunicações, pesquisas, relatos de experiência, resenhas e dossiês. Entendemos essa pluralidade como expressão do mundo em que vivemos e no qual a escola está inserida. Não há uma escola assim como não há educação pensada a priori. Em tempos de ataques cotidianos ao ensino público como espaço de formação, mas também de criação, liberdade e inventividade, nossa intenção primordial diz respeito a subverter cenários que relegam (ou reduzem) a educação e a escola a lógicas instrumentais, estéreis e unificadoras.

A Revista ETD, pensada coletivamente nos termos acima referidos, orgulha-se de ter conseguido realizar tais princípios, que nos servem de balizas. Se nossos alicerces estão fincados no campo educacional, um exame apurado do conjunto de textos publicados em 2018 traz à tona um verdadeiro mosaico de áreas, temas, conceitos, práticas e epistemologias. Por aparente contradição, da não homogeneidade de visões e perspectivas emerge a riqueza (e a força) que buscamos: tal qual um caleidoscópio, a cada

\footnotetext{
1 Pós-doutorado e Doutor em Sociologia - Universidade Estadual de Campinas (UNICAMP) - Campinas, SP - Brasil. Professor da Universidade Estadual de Campinas, Faculdade de Educação (UNICAMP/FE) - Campinas, SP - Brasil. E-mail: acdiasjr@gmail.com

2 Pós-doutorado - Universidade do Minho/Portugal. Doutor em Educação - Universidade Estadual de Campinas (UNICAMP) - Campinas, SP - Brasil. Professor da Universidade Estadual de Campinas (UNICAMP/FE) - Campinas, SP Brasil. E-mail: wenceslao.oliveira@gmail.com
}

(C) ETD-Educação Temática Digital Campinas, SP $\quad$ v.20 $\quad$ n.4 $\quad$ p. $862-863 \quad$ out./dez. 2018 
movimento/leitura temos novas combinações, recombinações e possibilidades. A potência que deriva da multiplicidade fortifica nossas pretensões. Nos alimenta, anima e revigora.

O leitor e a leitora encontrarão neste número que fecha o volume 20 de nossa publicação quatorze artigos inéditos e uma revisão de literatura. Autores e autoras ligados e ligadas a diferentes instituições e sob diferentes epistemologias apresentam suas respectivas contribuições, como feixes de luz a atravessar os espelhos e os fragmentos de vidro de nosso caleidoscópio metafórico. Caberá a cada um e a cada uma visualizar as imagens produzidas, com seus formatos e cores, sempre em constante mutação.

As fotografias registraram a natureza caleidoscopicamente ao longo dos dois últimos séculos, nos oferecendo múltiplas miradas para aquilo que, em nossa cultura ocidental, seria externo ao humano, à cultura. Ainda que externa, o campo da educação ocidental utilizou-se de metáforas naturais, em especial vegetais, para edificar vários de seus percursos de pensamento, dos jardins de Comênio aos rizomas da filosofia da diferença.

A imagem da capa nos remete tanto à exuberância quanto à resistência: no plano do registro figurativo vemos raízes soltas sob um chão que se desfaz e, justamente por isso, expõe as raízes; no plano da imagem vemos emaranhados de linhas que fazem subir e descer os olhos ao mesmo tempo que permitem ver dois grandes blocos: de sombras, abaixo, e brilhos, acima. Mesmo sem o solo à sua volta, as raízes se mantêm vivas - por quanto tempo ainda? - e as plantas que crescem sobre esse chão que se desfaz remetem a um tipo de vida que não capitula à erosão daquilo que aparentemente a sustentava. A vida da imagem, aquilo que nos faz ver nela algo mais que registros figurativos, se apropria dessa resistência figurada para expressar, em brilhos e sombras, em beleza e angústia e nostalgia, algo que extrapola a figuração nela apresentada.

Às vésperas do primeiro vestibular voltado ao ingresso de estudantes dos povos indígenas, a fotografia de capa busca expressar a não externalidade da natureza à cultura, conforme nos apontam as filosofias ameríndias, e tornar pública a alegria da Revista ETD Educação Temática Digital pela abertura da Faculdade de Educação e da Universidade Estadual de Campinas aos povos que pensam suas vidas, o mundo e a educação como sendo parte da natureza, compostos por ela, internamente. Acreditamos que, com esses povos entre nós, a vida seguirá mais viva, múltipla em seus jardins e rizomas, em suas folhas, raízes e caules, constituindo para si mesma outros tipos de chão.

Boa leitura! 